\title{
ZARZĄDZANIE STRATEGICZNE W DUŻYCH MIASTACH W POLSCE
}

\section{WSTĘP}

Celem niniejszego artykułu jest ocena poziomu zarządzania strategicznego, rozumianego jako właściwa realizacja poszczególnych etapów cyklu strategicznego, w dużych miastach w Polsce. Badanie oparto na analizie porównawczej obowiązujących dokumentów strategicznych, informacjach z oficjalnych stron internetowych miast poświęconych strategii, a także dokumentach wdrożeniowych i raportach z realizacji strategii. Zakres przestrzenny analizy obejmuje siedem największych miast w Polsce: Gdańsk, Katowice, Kraków, Łódź, Poznań, Warszawa i Wrocław, wybranych według kryterium liczby ludności. Podstawową przesłanką takiego wyboru było założenie, że ze względu na duże zasoby organizacyjne i kadrowe mają one największą możliwość pełnej realizacji cyklu strategicznego.

Podejmowana tematyka jest stosunkowo rzadko analizowana praktycznie w polskiej literaturze. Tymczasem po okresie upowszechniania się planowania strategicznego coraz bardziej wzrasta rola właściwego zarządzania (governance) $^{1}$ i monitorowania strategii ${ }^{2}$. Podejście to wynika z założenia, że dokumenty strategiczne powinny przekładać się na rzeczywiste zmiany sytuacji miasta, w tym osiagnięcie korzyści przez grupy docelowe. Wymaga to ścisłego powiązania systemu monitoringu strategicznego z zarządzaniem strategicznym tak, aby decyzje zarządcze były oparte na faktach. Dobre funkcjonowanie tych elementów jest jednak zależne od przebiegu wcześniejszych etapów cyklu strategicznego. Dobrze zaprojektowany system monitoringu powinien być tworzony równocześnie z interwencją publiczną, której dotyczy, co nie jest powszechne.

\section{ZARZĄDZANIE STRATEGICZNE I JEGO ZASTOSOWANIE W MIASTACH}

Upowszechnienie planowania strategicznego w polskich miastach budzi refleksję nad poziomem ich zaawansowania w dziedzinie zarządzania strategicznego. $\mathrm{W}$ ujęciu biznesowym ${ }^{3}$ zarządzanie jest rozumiane jako „zestaw działań

\footnotetext{
${ }^{1}$ Rolę zarządzania w miastach i sektorze publiczny analizowali m.in.: S. P. Osborne, The New Public Governance, „Public Management Review” 8, 2006, s. 377-387; UNESCAP, What Is a Good Governance, 2009, http://www.unescap.org/resources/what-good-governance; London School of Economics - Program Cities: http://www.lse.ac.uk/LSECities/home.aspx.

${ }^{2}$ Kwestie poruszane m.in. w: D. Johnstone, Squaring the Circle: Evidence at the Local Level, 2014, NESTA, Alliance for Useful Evidence, publikacja elektroniczna; M. Matusiak, w: Guideline Note for a Monitoring and Evaluation System for Innovation Strategies (RIS3) in Poland, World Bank Working Papers 2015.

${ }^{3}$ R. W. Griffin, Podstawy zarzqdzania organizacjami, WN PWN, Warszawa 2013, s. 6.
} 
(obejmujący planowanie i podejmowanie decyzji, organizowanie, przewodzenie, tj. kierowanie ludźmi, i kontrolowanie) skierowanych na zasoby organizacji (ludzkie, finansowe, rzeczowe i informacyjne) i wykonywanych z zamiarem osiagnięcia celów organizacji w sposób sprawny i skuteczny". Zarządzanie strategiczne to natomiast zestaw działań i decyzji prowadzących do formułowania i wdrażania planów ukierunkowanych na osiagnięcie celów danej organizacji ${ }^{4}$, ocenę rezultatów tych strategii, poprawę ich niespójności lub kierunków działania i aktualizację strategii ${ }^{5}$. Wszystkie cytowane definicje wskazuja na etap planowania jedynie jako jeden z elementów zarządzania, które powinno doprowadzić nie tylko do wyznaczenia, ale również osiągnięcia celów organizacji.

Ze względu na specyfikę miast jako organizacji zdefiniowano również zarządzanie strategiczne miastem (urban governance), które w ujęciu podstawowym należy rozumieć jako sposoby wykorzystywane przez osoby i instytucje publiczne oraz prywatne do planowania i pomiaru funkcjonowania miasta ${ }^{6}$. Nowsze definicje podkreślają rolę zaawansowanego potencjału instytucjonalnego, narzędzi demokratycznych oraz efektywnego zarządzania pozwalającego miastom na radzenie sobie ze wzrastającą złożonością wyzwań społecznych, gospodarczych i środowiskowych oraz wykorzystaniem nowych technologii ${ }^{7}$.

Cechą różniącą definicje planowania strategicznego w miastach od definicji biznesowych jest ich większa otwartość, polegająca na zaangażowaniu różnego typu interesariuszy publicznych i prywatnych oraz podkreśleniu roli dialogu i demokratyzacji procesu planowania i wdrażania strategii. Definicje te pokrywają się również z metodologią planowania strategicznego w sektorze publicznym $^{8}$, w której podkreśla się konieczność realizacji pełnego cyklu strategicznego, w tym zarządzania i monitoringu, ale również potrzebę zbudowania właściwej kultury organizacyjnej sprzyjającej realizacji strategii.

Strategia rozumiana jako kompleksowy plan osiagania celów organizacji ${ }^{9}$ wiąże się z pojęciem cyklu strategicznego - następujących po sobie i współwystępujących sekwencji planowania, wdrażania, finansowania i monitoringu strategii, co jest podstawą właściwego zarządzania strategicznego (diagram 1). W prawidłowo przebiegającym cyklu strategicznym poszczególne etapy zazębiają się i przenikaja. W sytuacji planowania strategii wdrażanej przez urząd miasta już na początkowym etapie powinny powstać ustalenia organizacyjne i proceduralne pozwalające na jej wdrożenie. Zadania wynikające ze strategii powinny podlegać szacowaniu kosztów i powiązaniu z budżetem zadaniowym oraz zewnętrznymi źródłami finansowania, a wydatkowane nakłady powinny być na bieżąco monitorowane.

Zgodnie z wytycznymi Komisji Europejskiej na nowy okres programowania (2014-2020) monitoring powinien obejmować całą logikę interwencji, w tym

${ }^{4}$ J. A. Pearce, R. B. Robinson, Formulation, Implementation and Control of a Competitive Strategy, wyd. 10, McGraw-Hill/Irwin, New York 2007, s. 3.

${ }^{5}$ J. M. Bryson, Strategic Planning for Public and Nonprofit Organizations. A Guide to Strengthening and Sustaining Organizational Achievement, wyd. 3, John Wiley and Sons, San Francisco 2004, s. 32 i 238

${ }^{6}$ GRDC, Programme on Urban Governance, http://www.gdrc.org/u-gov/ugov-define.html.

${ }^{7}$ London School of Economics, op. cit.

8 Prezentowana w J. M. Bryson, op. cit.

${ }^{9}$ R. W. Griffin, op. cit., s. 245. 
wskaźniki nakładu, produktu i rezultatu, a na poziomie ewaluacji - również rezultatu strategicznego (oddziaływania) ${ }^{10}$. Wreszcie, wyniki monitoringu i ewaluacji powinny być na bieżąco przekładane na sposób wdrażania strategii, by w ten sposób przyczyniać się do poprawy jej efektywności i skuteczności. W razie konieczności informacje te należy również wykorzystywać do planowania zmian strategii, kiedy osiagane efekty zostaną uznane za niewystarczające. Dopiero pełna realizacja cyklu strategicznego pozwala na prowadzenie tzw. polityki opartej na faktach, pozwalającej na właściwą priorytetyzację działań i wytwarzanie mierzalnej wartości publicznej.

\section{Diagram 1}

Cykl strategiczny z uwzględnieniem etapu finansowania

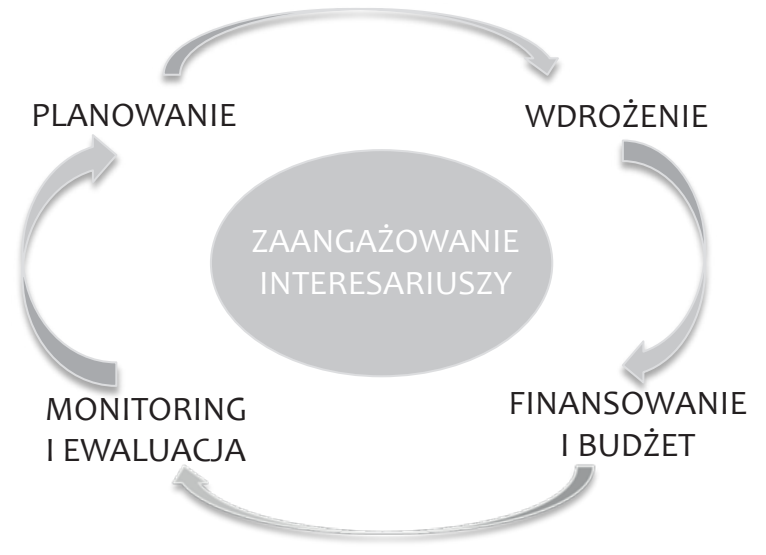

Źródło: opracowanie własne.

Etap planowania strategicznego w kontekście rozwoju miast oznacza konieczność zaangażowania interesariuszy wewnętrznych - od radnych po dyrektorów wydziałów i szefów jednostek miejskich, a także szerokie uspołecznienie procesu - zarówno przez zapewnienie udziału czołowych instytucji i organizacji, jak i analizę opinii mieszkańców. Uspołecznienie oznacza tu coś więcej niż standardowe konsultacje społeczne - angażuje bowiem interesariuszy w sposób partycypacyjny już od momentu rozpoczęcia procesu planowania. Inną istotną kwestią jest potraktowanie planowania strategicznego jako planowania zmiany, czyli z uwzględnieniem logiki interwencji - ciagu przyczynowo-skutkowego pomiędzy poszczególnymi poziomami celów strategii. Sposób zaplanowania i operacjonalizacji celów strategicznych przeanalizowano w dalszej części artykułu na przykładzie wybranych miast.

$\mathrm{Na}$ etapie wdrażania kluczowe jest powiązanie zadań wynikających ze strategii ze strukturą organizacyjną urzędu miasta, w tym przypisanie konkretnej odpowiedzialności za realizację zaplanowanych zadań oraz ich powiązanie ze strukturą zarządzania miastem. Ważnym elementem praktycznego zarządza-

${ }^{10}$ Komisja Europejska, DG Regio 2014, http://ec.europa.eu/regional_policy/sources/docoffic/2014/working/wd_2014_en.pdf. 
nia strategicznego może być powiązanie systemu zarządzania strategicznego z systemem zarządzania projektami, a w wersji zaawansowanej - również z systemem zarządzania jakością oraz usługami publicznymi świadczonymi przez miasto. Szczegółowe rozwiązania związane z praktycznym wdrażaniem strategii w badanych miastach przedstawiono w dalszej części artykułu.

Etap finansowania nie jest często wskazywany jako osobny element cyklu strategicznego, w niniejszym artykule wyróżniono go jednak ze względu na to, że jest często pomijany w zarządzaniu strategicznym polskimi miastami. Powoduje to, że wiele strategii nie jest wdrażanych i pozostają one zapisami o charakterze życzeniowym. Bardzo rzadko moment prezentacji strategii wiaże się z przedstawieniem jej kosztów, planowanych nakładów na jej realizację i realistycznych źródeł finansowania. Przełożenie strategii na możliwości realizacyjne wiąże się z jej powiązaniem z wieloletnim planem finansowym i budżetem zadaniowym. Dodatkowo należy zaplanować strategię pozyskiwania środków zewnętrznych na realizację planowanych działań.

Tabela 1

Cykl strategiczny a dobre zarządzanie

\begin{tabular}{|c|c|l|}
\hline Lp. & $\begin{array}{c}\text { Element cyklu } \\
\text { strategicznego }\end{array}$ & Cechy dobrego zarządzania miastem \\
\hline 1. & Planowanie & $\begin{array}{l}- \text { partycypacja } \\
- \text { orientacja na konsensus } \\
- \text { wizja strategiczna }\end{array}$ \\
\hline 2. & Wdrożenie & $\begin{array}{l}- \text { partycypacja (w modelach zaawansowanych) } \\
- \text { skuteczność }\end{array}$ \\
\hline 3. & Finansowanie i budżet & $\begin{array}{l}- \text { transparentność } \\
- \text { efektywność }\end{array}$ \\
& & - rozliczalność \\
\hline 4. & Monitoring i ewaluacja & $\begin{array}{l}- \text { partycypacja (w modelach zaawansowanych) } \\
- \text { transparentność }\end{array}$ \\
& &
\end{tabular}

Źródło: opracowanie własne.

Etap monitoringu i ewaluacji jest kluczowy dla oceny efektów realizowanych działań oraz wykorzystania pozyskanych informacji w podejmowaniu decyzji o charakterze strategicznym, taktycznym i operacyjnym. Z jednej strony powinien on być zaplanowany już na etapie opracowywania strategii, tak aby analizowane wskaźniki właściwie obrazowały zmianę strategiczna, a z drugiej jego wyniki powinny przekładać się na bieżące wdrażanie strategii oraz na jej okresowe aktualizacje o charakterze długookresowym. Ostatnio można zaobserwować coraz większe zainteresowanie problemem monitoringu strategii i samego rozwoju miasta (np. system SAS), w niewielkim stopniu przekłada się ono jednak na tworzenie wiarygodnych i transparentnych systemów monitoringu i ewaluacji strategii.

Analiza strategii przyjmowanych przez polskie miasta pozwala stwierdzić, że mimo szerokiego upowszechnienia się etapu planowania strategicznego, pozostałe elementy cyklu strategicznego tworzace pełne zarządzanie strate- 
giczne powinny być znacząco wzmocnione. Zaawansowanie w tym procesie zostanie przeanalizowane w dalszej części niniejszego artykułu.

Cechy dobrego zarządzania miastem zdefiniowane w ramach jednego z programów ONZ ${ }^{11}$ wskazują na istotność partycypacji, rządów prawa i demokracji, transparentności, responsywności, orientacji na konsensus, równości, efektywności i skuteczności, rozliczalności oraz wizji strategicznej. Większość z wymienionych cech, z wyjątkiem rządów prawa i demokracji oraz równości, które są w Polsce regulowane na poziomie krajowym, jest powiązana z cyklem strategicznym (tab. 1). W szczególności demokratyzacja procesu planowania i wdrażania strategii poprzez szeroką partycypację interesariuszy wewnętrznych i zewnętrznych, skuteczność rozumiana jako osiaganie celów rozwojowych, efektywność kosztowa czy transparentność jako podstawa dialogu społecznego wskazują na istotne kwestie zwiazane z planowaniem strategicznym w sektorze publicznym. Można zatem stwierdzić, że prawidłowa realizacja pełnego cyklu strategicznego jest podstawą dobrego zarządzania miastem.

\section{PLANOWANIE STRATEGICZNE W DUŻYCH MIASTACH W POLSCE}

W ostatnich latach można zaobserwować stopniowa poprawę jakości powstających dokumentów strategicznych i stopniowe wprowadzanie bardziej zaawansowanych narzędzi planistycznych w samorządach lokalnych. Planowanie często nie obejmuje jednak pełnego cyklu strategicznego (diagram 1), a zwłaszcza takich etapów, jak wdrożenie, odpowiednie finansowanie oraz regularne monitorowanie i ewaluacja. Samo planowanie pozostaje na dość ogólnym poziomie, a większość strategii ma raczej charakter kierunkowy niż szczegółowo zaplanowanej i możliwej do wdrożenia zmiany strategicznej (tab. 2).

$\mathrm{W}$ tabeli 2 zaprezentowano wybrane cele z opublikowanych, aktualnych dokumentów strategicznych dużych miast w Polsce. Ze względu na to, że sa one budowane w oparciu o podobna logikę, w tabeli przedstawiono przykładowe zapisy dla różnych dziedzin objętych strategią tak, aby przedstawić ich pełne spektrum. Prezentowane cele stanowia jedynie element analizowanych dokumentów strategicznych, oddają jednak ich charakter i specyfikę poszczególnych strategii. Wszystkie odzwierciedlają jeden poziom - celów strategicznych, a ich analiza według kryterium SMART, zalecanego w literaturze i poradnikach praktycznych, w tym wytycznych Ministerstwa Infrastruktury i Rozwoju ${ }^{12}$, potwierdza ich ogólny i niemierzalny charakter. Badane cele maja charakter dość generalny, co jest dopuszczalne na poziomie strategicznym pod warunkiem późniejszego określenia jasnego kierunku działań i doborze wskaźników kontekstowych, które uszczegółowiają treści celu. Te ostatnie określono jedynie w dwóch z siedmiu badanych strategii - w Poznaniu i Katowicach.

11 UNESCAP, op. cit.

12 W. Dziemianowicz et al., Planowanie strategiczne. Poradnik dla pracowników administracji publicznej, Ministerstwo Rozwoju Regionalnego, Warszawa 2012, s. 139-140. 


\section{Tabela 2}

Przykładowe cele strategii rozwoju dużych polskich miast w kontekście zasady SMART ${ }^{*}$

\begin{tabular}{|c|c|c|c|c|}
\hline Lp. & Miasto & Poziom celu & Zapis celu & Ocena wg kryterium SMART \\
\hline 1. & Gdańsk & $\begin{array}{l}\text { Cel } \\
\text { strategiczny }\end{array}$ & $\begin{array}{l}\text { Tworzenie sku- } \\
\text { tecznego systemu } \\
\text { wielostopniowej } \\
\text { edukacji na każdym } \\
\text { etapie życia, w tym } \\
\text { zawodowej, elastycz- } \\
\text { nie podążającego za } \\
\text { rozwojem technolo- } \\
\text { gicznym oraz potrze- } \\
\text { bami gospodarki, } \\
\text { dającego miejsce na } \\
\text { rynku pracy wszyst- } \\
\text { kim uczestnikom } \\
\text { procesu kształcenia }\end{array}$ & $\begin{array}{l}\text { 1. Szczegółowy - cel szczegółowy, choć } \\
\text { bardzo szeroki } \\
\text { 2. Mierzalny - brak wskaźników monito- } \\
\text { ringu bezpośrednio odzwierciedlających } \\
\text { realizację celu } \\
\text { 3. Akceptowalny - strategia powstała } \\
\text { w procesie partycypacyjnym, cel można } \\
\text { więc uznać za akceptowalny } \\
\text { 4. Realny - ze względu na to, że założony cel } \\
\text { leży w dużej mierze poza bezpośrednimi } \\
\text { kompetencjami władz miasta, jest mało } \\
\text { realny. Ponadto brak informacji o możli- } \\
\text { wościach finansowania realizacji celu } \\
\text { Terminowy - nieokreślony termin rea- } \\
\text { lizacji }\end{array}$ \\
\hline 2. & Katowice & $\begin{array}{l}\text { Cel } \\
\text { strategiczny }\end{array}$ & $\begin{array}{l}\text { Katowice interdy- } \\
\text { scyplinarnym ośrod- } \\
\text { kiem akademickim } \\
\text { o renomie między- } \\
\text { narodowej generują- } \\
\text { cym kapitał ludzki } \\
\text { wysokiej jakości }\end{array}$ & $\begin{array}{l}\text { 1. Szczegółowy - cel o charakterze ogól- } \\
\text { nym } \\
\text { 2. Mierzalny - do celu dobrano wskaźniki } \\
\text { realizacji o charakterze kontekstowym } \\
\text { 3. Akceptowalny - strategia powstała na } \\
\text { podstawie konsultacji z interesariusza- } \\
\text { mi wewnętrznymi i zewnętrznymi, ale } \\
\text { bez pełnej partycypacji mieszkańców } \\
\text { 4. Realny - ze względu na to, że założony } \\
\text { cel leży całkowicie poza bezpośrednimi } \\
\text { kompetencjami władz miasta, jest mało } \\
\text { realny. Ponadto brak informacji o możli- } \\
\text { wościach finansowania realizacji celu } \\
\text { Terminowy - nieokreślony termin rea- } \\
\text { lizacji }\end{array}$ \\
\hline 3. & Kraków & $\begin{array}{l}\text { Cel } \\
\text { strategiczny }\end{array}$ & $\begin{array}{l}\text { Kraków miastem } \\
\text { przyjaznym rodzinie, } \\
\text { atrakcyjnym miej- } \\
\text { scem zamieszkania } \\
\text { i pobytu }\end{array}$ & $\begin{array}{l}\text { 1. Szczegółowy - cel o charakterze ogól- } \\
\text { nym, bardzo szeroki } \\
\text { 2. Mierzalny - nie określono wskaźników } \\
\text { realizacji } \\
\text { 3. Akceptowalny - dokument nie wspomina } \\
\text { o jakichkolwiek procesach partycypa- } \\
\text { cyjnych } \\
\text { 4. Realny - realizacja celu leży w kom- } \\
\text { petencjach władz miasta, ale stopień } \\
\text { ogólności utrudnia ocenę realności osią- } \\
\text { nięcia celu } \\
\text { 5. Terminowy - nieokreślony termin rea- } \\
\text { lizacji }\end{array}$ \\
\hline
\end{tabular}

* Zasada SMART oznacza, że cel strategiczny powinien być szczegółowy, mierzalny, akceptowalny, realny i terminowy. 


\begin{tabular}{|c|c|c|c|c|}
\hline Lp. & Miasto & Poziom celu & Zapis celu & Ocena wg kryterium SMART \\
\hline 4. & Eódź & $\begin{array}{l}\text { Cel } \\
\text { strategiczny }\end{array}$ & $\begin{array}{l}\text { Nowe Centrum } \\
\text { Łodzi - stworzenie } \\
\text { służącego realizacji } \\
\text { wizji nowoczesnego } \\
\text { obszaru aktywności } \\
\text { społecznej i gospo- } \\
\text { darczej o bardzo } \\
\text { dobrej dostępności } \\
\text { komunikacyjnej }\end{array}$ & $\begin{array}{l}\text { 1. Szczegółowy - cel o charakterze ogól- } \\
\text { nym } \\
\text { 2. Mierzalny - nie określono wskaźników } \\
\text { realizacji } \\
\text { 3. Akceptowalny - dokument nie wspomi- } \\
\text { na o żadnych procesach partycypacyj- } \\
\text { nych } \\
\text { 4. Realny - realizacja celu leży w kompe- } \\
\text { tencjach władz miasta, ale pociaga za } \\
\text { sobą znaczne nakłady finansowe, któ- } \\
\text { rych źródła nie określono } \\
\text { 5. Terminowy - nieokreślony termin rea- } \\
\text { lizacji }\end{array}$ \\
\hline 5. & Poznań & $\begin{array}{l}\text { Cel } \\
\text { strategiczny }\end{array}$ & $\begin{array}{l}\text { Rozwój gospodarki } \\
\text { innowacyjnej i pod- } \\
\text { noszenie atrakcyj- } \\
\text { ności inwestycyjnej } \\
\text { miasta }\end{array}$ & $\begin{array}{l}\text { 1. Szczegółowy - cel o charakterze ogól- } \\
\text { nym } \\
\text { 2. Mierzalny - do celu dobrano wskaźniki } \\
\text { realizacji o charakterze kontekstowym } \\
\text { 3. Akceptowalny - strategia powstała } \\
\text { w procesie partycypacyjnym, cel można } \\
\text { więc uznać za akceptowalny } \\
\text { 4. Realny - osiagnięcie celu częściowo leży } \\
\text { w kompetencjach władz miasta, cel jest } \\
\text { więc możliwy do przynajmniej częścio- } \\
\text { wej realizacji } \\
\text { 5. Terminowy - nieokreślony termin rea- } \\
\text { lizacji }\end{array}$ \\
\hline 6. & Wrocław & $\begin{array}{l}\text { Cel - } \\
\text { wytyczne }\end{array}$ & $\begin{array}{l}\text { Stworzenie należ- } \\
\text { nych mieszkańcom } \\
\text { wielkiego miasta } \\
\text { warunków do psy- } \\
\text { chicznego i fizyczne- } \\
\text { go odprężenia przez } \\
\text { sport i rekreację }\end{array}$ & $\begin{array}{l}\text { 1. Szczegółowy - cel o charakterze ogól- } \\
\text { nym } \\
\text { 2. Mierzalny - nie określono wskaźników } \\
\text { realizacji } \\
\text { 3. Akceptowalny - dokument nie wspomi- } \\
\text { na o żadnych procesach partycypacyj- } \\
\text { nych } \\
\text { 4. Realny - realizacja celu leży w kom- } \\
\text { petencjach władz miasta, cel jest więc } \\
\text { możliwy do osiagnięcia } \\
\text { 5. Terminowy - nieokreślony termin rea- } \\
\text { lizacji }\end{array}$ \\
\hline 7. & Warszawa & $\begin{array}{l}\text { Cel } \\
\text { strategiczny }\end{array}$ & $\begin{array}{l}\text { Wzmocnienie po- } \\
\text { czucia tożsamości } \\
\text { mieszkańców po- } \\
\text { przez pielęgnowanie } \\
\text { tradycji, rozwój } \\
\text { kultury i pobu- } \\
\text { dzanie aktywności } \\
\text { społecznej }\end{array}$ & $\begin{array}{l}\text { 1. Szczegółowy - cel o charakterze ogól- } \\
\text { nym } \\
\text { 2. Mierzalny - nie określono wskaźników } \\
\text { realizacji } \\
\text { 3. Akceptowalny - strategia powstała } \\
\text { w procesie partycypacyjnym, cel można } \\
\text { więc uznać za akceptowalny } \\
\text { 4. Realny - realizacja celu leży w kom- } \\
\text { petencjach władz miasta, cel jest więc } \\
\text { możliwy do osiagnięcia } \\
\text { 5. Terminowy - nieokreślony termin rea- } \\
\text { lizacji }\end{array}$ \\
\hline
\end{tabular}

Źródło: do opracowania tabeli (kolumna: Zapis celu) wykorzystano dokumenty strategiczne: Gdańsk 2030 Plus. Strategia Rozwoju Miasta; „Katowice 2020”. Strategia Rozwoju Miasta; Strategia Rozwoju Krakowa; Strategia Rozwoju Miasta Poznania do roku 2030; Strategia Rozwoju m.st. Warszawy do 2020 roku; Strategia „Wrocław w perspektywie 2020 plus”; Strategia Zintegrowanego Rozwoju Łodzi 2020+. 
W analizowanej grupie strategii cele często wkraczają w obszary niezależne lub jedynie częściowo zależne od kompetencji władz miasta. Wynika to z przyjęcia rozumienia strategii rozwoju miasta jako czegoś więcej niż strategii samorządu lokalnego, co jednak utrudnia przypisanie odpowiedzialności za faktyczną realizację przyjętych kierunków działań. Oznacza to, że ich realizacja jest uzależniona od współpracy z dużym spektrum interesariuszy, w żadnym przypadku nie zdefiniowano jednak konkretnych procedur takiej współpracy. W żadnym analizowanym przypadku nie określono także terminu osiagnięcia celów strategicznych, należy więc przyjąć, że ich realizacja będzie trwała przez cały okres obowiązywania strategii. Ze względu na fakt, że perspektywy czasowej nie przyjęto również na poziomie celów operacyjnych (jedynie Poznań określił kluczowe projekty i przedsięwzięcia w kolejnych pięcioletnich etapach realizacji strategii) - nie jest możliwy regularny pomiar postępów w osiaganiu zaplanowanych zmian. Taki sposób sformułowania celów rozwojowych miast nie sprzyja prawidłowej realizacji późniejszych etapów cyklu strategicznego - wdrażaniu, finansowaniu i monitoringowi.

Wątpliwości budzi także kwestia demokratyzacji procesów strategicznych w miastach. Przytaczana powyżej definicja strategicznego zarządzania miastem podkreśla udział interesariuszy zewnętrznych, w tym mieszkańców, w procesie nie tylko planowania, ale również wdrażania strategii. Cztery (na siedem badanych) miasta przeprowadziły mniej lub bardziej zaawansowane procesy partycypacyjne, w tym również angażujące mieszkańców. Ich rola kończy się jednak na poziomie procesów planistycznych. Analizowane dokumenty strategiczne nie wskazuja na realną potrzebę udziału mieszkańców (i innych aktorów) w procesie wdrażania strategii lub ich włączenia w analizę postępów jej realizacji za pomoca transparentnych systemów monitoringu.

Skuteczna strategia wymaga operacjonalizacji, przeznaczenia konkretnych środków budżetowych na jej realizację oraz monitoringu postępów we wdrażaniu zaplanowanych działań. W większości badanych dokumentów, cele strategiczne podzielono na cele operacyjne, zazwyczaj także o dość ogólnym charakterze. W przypadku strategii Poznania, Krakowa, Warszawy i Katowic określono także szczegółowe działania lub zadania strategiczne, które pozwalają przełożyć ogólne założenia strategii na praktykę realizacyjną (tab. 3). Dobra formą operacjonalizacji sa programy strategiczne, których opracowanie założono w trzech miastach (Poznań, Gdańsk, Warszawa), choć tylko w Poznaniu zostały one faktycznie przygotowane i stanowią istotną część strategii. Inne miasta (Łódź i Kraków, planowane we Wrocławiu) zdecydowały się powiązać istniejąca politykę sektorową (np. polityka transportowa lub strategia rozwiązywania problemów społecznych) ze strategia. W tym ostatnim przypadku problemem staje się powiązanie z celami polityki sektorowej celów strategii, których zakres jest często zdefiniowany ustawowo i nie w pełni pokrywa się z zapisami strategii rozwoju miasta. 
Tabela 3

Formy operacjonalizacji strategii

\begin{tabular}{|c|c|c|}
\hline Lp. & Miasto & Forma operacjonalizacji \\
\hline 1. & Gdańsk & $\begin{array}{l}\text { - zaplanowano dziewięć programów operacyjnych zawierających } \\
\text { zadania i projekty - do tej pory nieopracowane }\end{array}$ \\
\hline 2. & Katowice & $\begin{array}{l}\text { - dobór kierunków działania dla każdego z celów strategicznych } \\
\text { - identyfikacja projektów dla tzw. pól strategicznych } \\
\text { - powiązanie z programami miejskimi }\end{array}$ \\
\hline 3. & Kraków & $\begin{array}{l}\text { - programy sektorowe dla każdego celu operacyjnego - obowiązu- } \\
\text { jące i przygotowywane } \\
\text { - } \text { priorytetowe projekty inwestycyjne }\end{array}$ \\
\hline 4. & Łódź & $\begin{array}{l}\text { - } \text { uszczegółowienie sposobu osiagnięcia celu w opisie } \\
\text { - } \text { polityka sektorowa (uchwalono } 6 \text { z } 7 \text { programów i strategii sek- } \\
\text { torowych) zawierajacca cele, zadania, budżet i termin realizacji } \\
\text { - } \text { planowane programy operacyjne - do tej pory nieopracowane }\end{array}$ \\
\hline 5. & Poznań & $\begin{array}{l}\text { - } 18 \text { programów strategicznych (w ramach strategii) zawierają- } \\
\text { cych działania strategiczne, kluczowe projekty i przedsięwzię- } \\
\text { cia, wskaźniki realizacji oraz szacunkowe nakłady na realizację }\end{array}$ \\
\hline 6. & Wrocław & $\begin{array}{l}\text { - zaplanowane średniookresowe plany rozwoju społeczno-gospo- } \\
\text { darczego - do tej pory nieopracowane } \\
\text { - } \text { corocznie publikowane założenia polityki społeczno-gospodarczej } \\
\text { Wrocławia przedstawiające liczbę realizowanych zadań w ra- } \\
\text { mach priorytetów strategicznych na dany rok }\end{array}$ \\
\hline 7. & Warszawa & $\begin{array}{l}\text { - programy w ramach celów operacyjnych - ogólnie opisane } \\
\text { w tekście strategii, z przypisanymi zadaniami } \\
\text { - } \text { programy związane ze społeczną strategią rozwoju Warszawy - } \\
\text { o charakterze polityki społecznej }\end{array}$ \\
\hline
\end{tabular}

Źródło: opracowanie własne na podstawie dokumentów strategicznych (zob. tab. 2) analizowanych miast oraz ich oficjalnych stron internetowych.

O ile powiązanie programów i strategii sektorowych ze strategia jest istotne, o tyle należy zwrócić uwagę na konieczność zaplanowania logiki interwencji o charakterze przyczynowo-skutkowym. Oznacza to, że każda strategia powinna być oparta na drzewie celów (diagram 2), gdzie realizacja działań strategicznych pozwala na osiagnięcie celów operacyjnych (pośrednich/szczegółowych), a to z kolei pozwala na osiągnięcie celów strategicznych (głównych). Wysoki stopień złożoności systemów miejskich powoduje, że najlepszym sposobem uporządkowania systemu celów w strategii są wspomniane już programy strategiczne, rekomendowane również w literaturze dotyczącej planowania strategicznego $\mathrm{w}$ sektorze publicznym ${ }^{13}$. 


\section{Diagram 2}

\section{Logika interwencji na przykładzie drzewa celów}

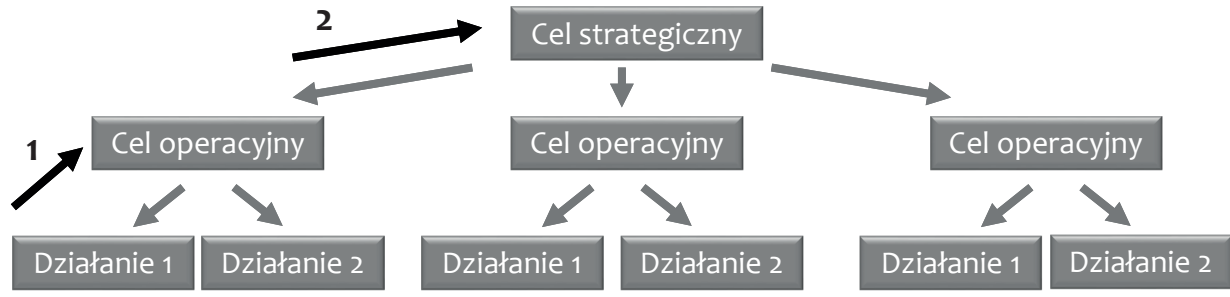

Pytania:

1. Czy realizacja zaplanowanych działań pozwoli osiągnąć dany cel operacyjny?

2. Czy realizacja celów operacyjnych pozwoli osiągnąć cel strategiczny i planowaną zmianę?

Źródło: opracowanie własne.

Problematyka strategii sektorowych pozwala na wskazanie kolejnej istotnej kwestii związanej z zarządzaniem strategicznym $\mathrm{w}$ miastach - relacji między zadaniami własnymi samorządów gminnych i powiatowych, w tym koniecznością świadczenia usług publicznych o charakterze społecznym, technicznym i administracyjnym, których zakres jest ściśle określony ustawowo, a przyjmowanymi celami strategii rozwoju miast, w których badane samorzady wykazują ambicje szersze niż wynikające z przypisanych im uprawnień. Taka sytuacja rodzi trzy rodzaje problemów:

- trudności w finansowaniu zadań, które nie wynikają bezpośrednio z zadań własnych samorządów;

- trudności w realizacji projektów niebędących w kompetencjach samorządów;

- oddzielenie operacyjno-taktycznej sfery funkcjonowania miasta (programów i strategii sektorowych i usług publicznych) od sfery strategicznej, która staje się w tym przypadku teoretyczna, lub realizowana „przy okazji”.

$\mathrm{O}$ ile pierwsze $\mathrm{z}$ dwóch wymienionych problemów można przezwyciężyć przez pozyskanie zewnętrznych źródeł finansowania lub skierowanie dodatkowych środków własnych z budżetów miast, lub wchodzenie w partnerstwo strategiczne z organizacjami zewnętrznymi (dotąd raczej niepraktykowane), o tyle oddzielenie bieżącego funkcjonowania miasta od kwestii strategicznych zaprzecza samej idei strategii, która powinna być głównym dokumentem kierunkujacym działania samorządu i będącym podstawą podejmowania decyzji taktycznych i operacyjnych.

\section{WDRAŻANIE STRATEGII}

Skuteczne wdrażanie strategii, poza opisana powyżej operacjonalizacja, wymaga przełożenia zadań na struktury organizacyjne samorządów, w tym w szczególności urzędów miast (m.in. zaangażowanie zasobów rzeczowych, finansowych i ludzkich tych organizacji). Klasyczne funkcje związane z zarządzaniem organizacja ${ }^{14}$ wiążą się z etapami cyklu strategicznego:

${ }^{14}$ R. W. Griffin, op. cit., s. 7-11. 
- funkcję planowania i podejmowania decyzji można przełożyć na etap planowania i operacjonalizację strategii w cyklu strategicznym, choć niektórzy autorzy traktują operacjonalizację jako etap wdrażania;

- funkcja organizowania odpowiada etapowi wdrażania - oznacza przełożenie na strukturę organizacyjną i finansowanie;

- funkcja przewodzenia to również etap wdrażania, w tym przełożenie ogólnych kierunków działania na zadania taktyczne i operacyjne oraz motywowanie pracowników;

- funkcja kontrolowania odpowiada monitoringowi i aktualizacji strategii.

W literaturze wskazuje się też na zależność skuteczności strategii od jej powiazania z kulturą organizacyjna ${ }^{15}$. W ocenie systemu wdrażania strategii za główne kryterium należy więc przyjąć kwestię powiązania strategii z funkcjonowaniem urzędu miasta i jednostek miejskich jako organizacji oraz znalezienie formuły współpracy z partnerami społeczno-gospodarczymi. Jedynie przypisanie odpowiedzialności strategicznej i powiązanie jej z działaniami operacyjnymi może bowiem sprawić, że cele długookresowe będą wpływały na podejmowanie decyzji krótkookresowych i zapewnią orientacyjną funkcję strategii w procesie decyzyjnym.

Badane miasta różnie podchodzą do wdrażania strategii (tab. 4). O ile przyjęty sposób operacjonalizacji strategii został opisany w poprzedniej części artykułu, o tyle kluczową dla systemu wdrażania kwestią jest przypisanie jasnej odpowiedzialności za realizację strategii, począwszy od szczebla zarządczego po taktyczno-operacyjny. Istotne jest więc przełożenie zadań wynikających ze strategii na strukturę organizacyjną urzędu miasta oraz określenie sposobu zaangażowania partnerów zewnętrznych, szczególnie w przypadku przyjęcia partycypacyjnego modelu wdrażania strategii. W przeciwnym wypadku istnieje duże zagrożenie, że strategia stanie się jedynie pustym dokumentem, który nie będzie generował realnej zmiany strategicznej.

W badanych miastach tylko w czterech na siedem przypadków (Gdańsk, Katowice, Poznań, Warszawa) dokonano próby przełożenia systemu realizacji strategii na strukturę organizacyjną urzędu miasta. O pełnym systemie organizacyjnym można mówić w przypadku istnienia ciała zarządzającego realizacją strategii - najczęściej Komitetu Sterującego, oraz koordynatorów poszczególnych celów lub programów strategicznych. O takiej strukturze można mówić w Katowicach, Warszawie i Poznaniu, przy czym w Warszawie informacje o działaniach Komitetu przestano publikować w 2013 r., a w Poznaniu i Katowicach nie sa one publikowane, zgodnie z założeniami strategii w Poznaniu Komitet spotyka się jednak co pół roku. Powiązanie strategii z programami i strategiami sektorowymi w Krakowie i Łodzi można również uznać za pewną formę przypisania do struktury organizacyjnej, za realizację programów i strategii sektorowych sa bowiem odpowiedzialne konkretne wydziały urzędu miasta. Nie do końca oznacza to jednak pełną odpowiedzialność za realizację konkretnych celów i zadań strategicznych, która nie została jasno określona. Najsłabiej zdefiniowano system wdrażania strategii we Wrocławiu, gdzie pozostaje on na etapie założeń.

15 J. M. Bryson, op. cit., s. 255. 


\section{Tabela 4}

System wdrażania strategii

\begin{tabular}{|c|c|c|}
\hline Lp. & Miasto & Przyjęty system wdrażania \\
\hline 1. & Gdańsk & $\begin{array}{l}\text { - } \text { założenie wdrażania przez programy operacyjne (do tej pory nie- } \\
\text { opracowane) } \\
\text { - } \text { założenie partycypacyjnego wdrażania strategii (brak informacji } \\
\text { o realizacji) } \\
\text { - } \text { wyznaczono koordynatorów i merytorycznych opiekunów progra- } \\
\quad \text { mów strategicznych }\end{array}$ \\
\hline 2. & Katowice & $\begin{array}{l}\text { - założenie powołania Komitetu Sterującego ds. realizacji strategii, } \\
\text { zespołu zadaniowego ds. wdrażania strategii rozwoju wraz z zespo- } \\
\text { łami problemowymi oraz zespołu ds. syntezy } \\
\text { - } \text { w dokumencie strategicznym określono skład wymienionych zespo- } \\
\text { łów oraz zakres ich zadań } \\
\text { - brak informacji o działalności zespołów }\end{array}$ \\
\hline 3. & Kraków & $\begin{array}{l}\text { - system wdrażania oparty na programach i strategiach sektorowych } \\
\text { i projektach inwestycyjnych, bez przypisania konkretnej odpowie- } \\
\text { dzialności za realizację celów strategicznych }\end{array}$ \\
\hline 4. & Łódź & 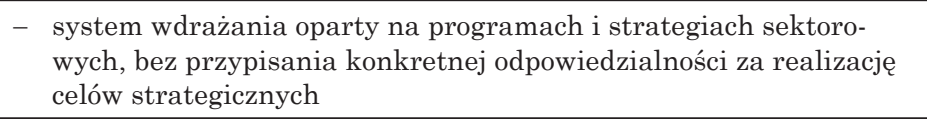 \\
\hline 5. & Poznań & $\begin{array}{l}\text { - } \text { powołano Komitet Sterujący dla strategii } \\
\text { - } \text { powołano Radę Strategii (o charakterze naukowym) } \\
\text { - } \text { przydzielono odpowiedzialność za strategię jednemu z wiceprezy- } \\
\text { dentów } \\
\text { - } \text { powołano promotorów programów strategicznych na poziomie wi- } \\
\text { ceprezydentów } \\
\text { - } \text { powołano przewodniczacych programów strategicznych (na pozio- } \\
\text { mie dyrektorów wydziałów) i określono ich zadania zarządzeniem } \\
\text { prezydenta } \\
\text { - } \text { wyznaczono rady programów strategicznych } \\
\text { - } \text { powiązano strategię z systemem zarządzania projektami }\end{array}$ \\
\hline 6. & Wrocław & $\begin{array}{l}\text { - } \text { założenie dotyczące partnerstw strategicznych (brak informacji } \\
\text { o realizacji) } \\
\text { - } \quad \text { założenie dotyczące powołania struktury organizacyjnej wyspecja- } \\
\text { lizowanej w prowadzeniu spraw nietypowych i zarządzaniu ryzy- } \\
\text { kiem (brak informacji o realizacji) } \\
\text { - } \text { założenie outsourcingu zadań strategicznych (brak informacji } \\
\text { o realizacji) } \\
\text { - } \text { brak przypisania zadań strategicznych w ramach struktury orga- } \\
\text { nizacyjnej urzędu } \\
\text { - } \\
\text { programy miejskie nie sa przypisane do celów strategicznych, lecz } \\
\text { wynikają z zapisów ustaw }\end{array}$ \\
\hline 7. & Warszawa & $\begin{array}{l}\text { - w dokumencie strategicznym brak informacji o systemie wdraża- } \\
\text { nia } \\
\text { - } \\
\text { - } \\
\text { zowołażenie powołania koordynatorów programów operacyjnych na } \\
\text { poziomie urzędu miasta (brak informacji o realizacji) } \\
\text { - } \\
\text { powołano koordynatorów ds. strategii na poziomie dzielnic }\end{array}$ \\
\hline
\end{tabular}

Źródło: opracowanie własne na podstawie dokumentów strategicznych analizowanych miast (zob. tab. 2) oraz ich oficjalnych stron internetowych. 
Za najbardziej rozbudowany system wdrażania można uznać podejście poznańskie, w którym strategia i programy strategiczne zostały przełożone na całą strukturę organizacyjną urzędu miasta (schemat 1), a dodatkowo zinstytucjonalizowano system uspołecznienia wdrażania strategii - począwszy od Rady Strategii zrzeszającej ekspertów ze świata nauki i biznesu oraz instytucji ważnych dla rozwoju miasta, której rola jest istotna na etapie planowania i aktualizacji dokumentu, po rady programów strategicznych i Oddział Dialogu Społecznego, których rola wzrasta na etapie wdrażania strategii.

\section{Schemat 1}

System wdrażania strategii w Poznaniu

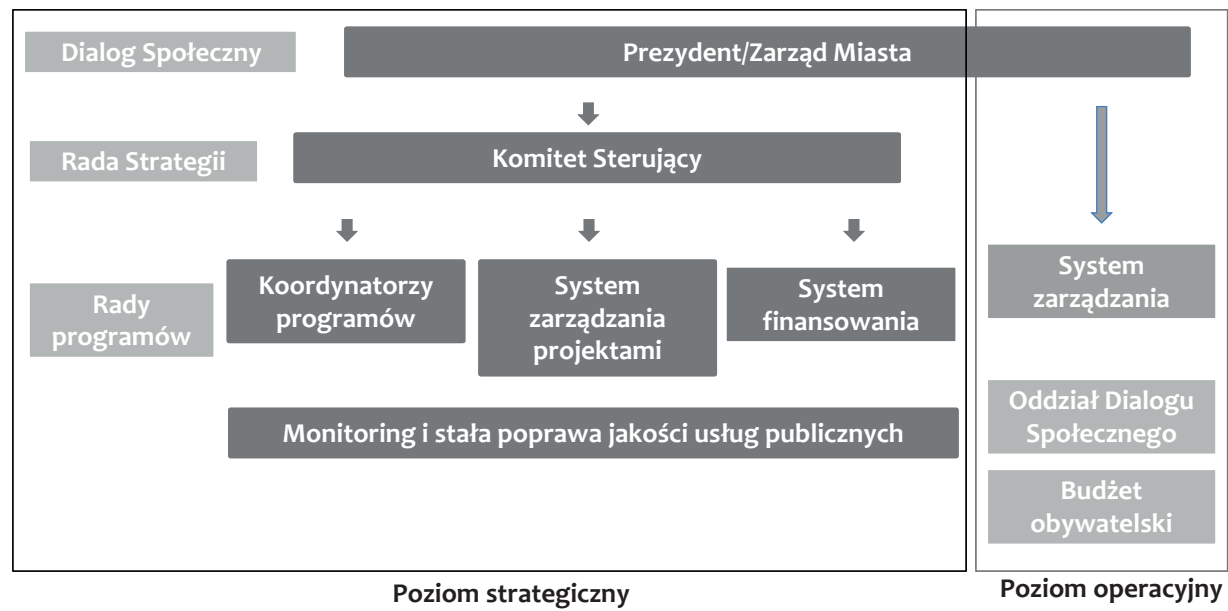

Źródło: opracowanie własne.

Właściwe określenie systemu wdrażania jest bardzo istotnym elementem cyklu strategicznego, pozwala bowiem na przejście do kolejnych etapów. W szczególności jasne określenie odpowiedzialności za realizację strategii pozwala na późniejsze monitorowanie postępów w jej realizacji i ocenę efektów. Poziom zaawansowania systemu wdrażania $\mathrm{w}$ badanych miastach można uznać za nie w pełni wystarczający do realizacji strategii i będący na różnych etapach rozwoju. Mimo że w większości badanych dokumentów strategicznych zaznaczono, że strategia traktowana jest jako dokument podstawowy dla rozwoju miasta, analiza realnego systemu wdrażania pozwala jednak stwierdzić, że założenie to jest $\mathrm{w}$ dużej mierze teoretyczne. W zasadzie jedynym miastem, gdzie można mówić o działającym systemie wdrażania, jest Poznań.

Taki stan może być spowodowany istniejacym rozrzutem między celami strategii a celami urzędu miasta jako organizacji. W strategiach biznesowych przyjęta strategia jest wyrazem celów przedsiębiorstwa. W sytuacji samorządów lokalnych istnieje wspomniana już luka pomiędzy zadaniami przypisanymi im ustawowo (zadania własne), wytycznymi dotyczącymi strategii sektorowych zawartymi w ustawach i rozporządzeniach, a celami, które tradycyjnie pojawiają się w strategiach i często wykraczają poza bezpośrednie kompeten- 
cje urzędów (np. konkurencyjność gospodarki). W takiej sytuacji cała struktura organizacyjna jest ukierunkowana na świadczenie usług publicznych i osiąganie celów innych (tylko częściowo zbieżnych) niż zapisane w strategii.

Wydaje się, że problem powiązania strategii rozwojowych z bieżącym funkcjonowaniem miast jest niezbędnym etapem pozwalającym na odejście od dokumentów o charakterze teoretycznym, a próby przekładania strategii na struktury organizacyjne urzędów świadczą o zainteresowaniu samorządów takimi działaniami. Szersze, partycypacyjne podejście do realizacji strategii wymaga natomiast stworzenia realnych struktur i platform współpracy umożliwiajacych aktorom lokalnym włączenie się w realizację celów i zadań strategicznych. Obecnie ich rola kończy się często na konsultacji kolejnych dokumentów strategicznych.

\section{FINANSOWANIE STRATEGII}

J. Bryson pisał, że „strategię wdraża się przez budżet”16. Oprócz organizacyjnych aspektów wdrażania niezbędne jest przypisanie konkretnych zasobów umożliwiających realizację strategii zgodnie z koncepcją klasycznego strategicznego łańcucha wyników, który można zinterpretować w kontekście strategii rozwoju miasta (schemat 2). Wskazuje on na konieczność przypisania do celów strategicznych zasobów ludzkich, finansowych i organizacyjnych umożliwiajacych ich osiąnięcie.

\section{Schemat 2}

Strategiczny łańcuch wyników

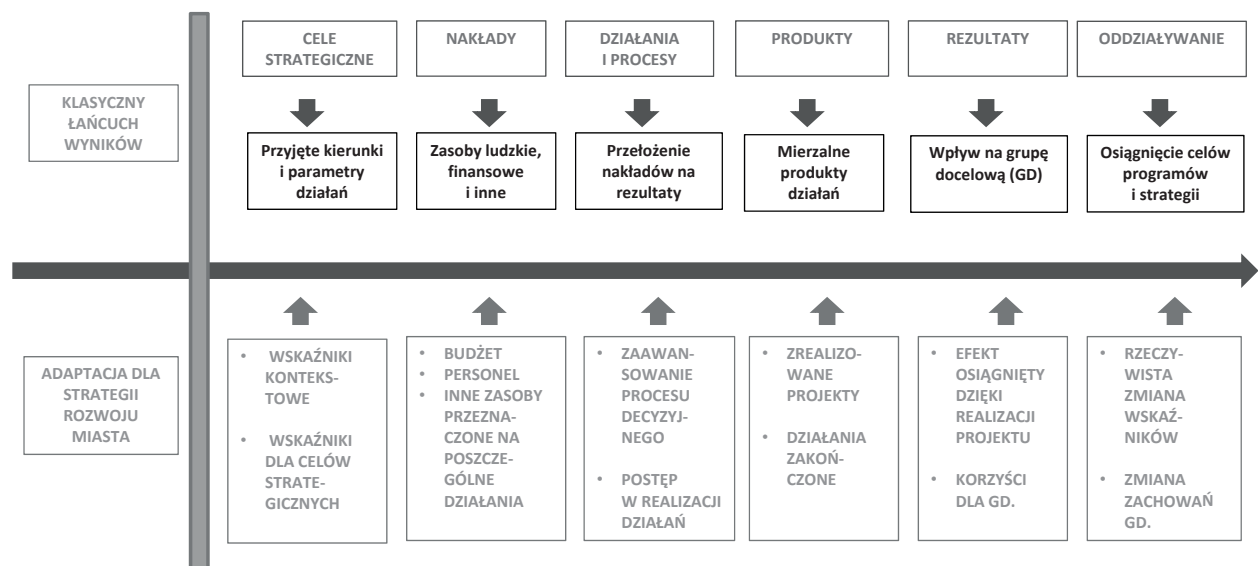

Źródło: opracowanie własne.

${ }^{16}$ J. M. Bryson, op. cit., s. 244-248. 
Finansowanie jest najsłabszym elementem analizowanych strategii. Większość dokumentów (Gdańsk, Katowice, Kraków, Łódź, Warszawa, Wrocław) w ogóle nie wspomina o źródłach finansowania strategii, często wymieniając jednocześnie konkretne projekty, w tym inwestycyjne, które powinny zostać zrealizowane. Jedynie w strategii rozwoju Poznania określono szacunkowe koszty realizacji strategii, w podziale na cele i programy strategiczne. Programy strategiczne finansowane są częściowo z budżetu miasta, a częściowo ze środków zewnętrznych, zarządzanie finansowaniem strategii przełożono też na strukturę organizacyjna.

Za decyzje finansowe odpowiada w Poznaniu Komitet Sterujacy, którego zadaniem jest integracja zarządzania strategicznego i wieloletniego planowania budżetowego. Opiniuje on także wszelkie projekty zgłaszane do realizacji w ramach systemu zarządzania projektami pod kątem ich zgodności ze strategią i możliwości finansowania. Co istotne, w ramach systemu monitoringu analizowane są coroczne nakłady na realizację celów i działań strategicznych w poszczególnych programach, a zadania wynikające ze strategii powiązano z budżetem zadaniowym. Takie podejście oznacza realne możliwości wdrożenia strategii na bazie określonych zasobów finansowych. Na poziomie programów i strategii sektorowych powiązanie z budżetem miasta i wieloletnia prognozą finansową przyjęto także w Łodzi, nie ma ono jednak bezpośredniego przełożenia na cele strategiczne.

\section{MONITORING I EWALUACJA}

Monitoring strategiczny może pełnić wiele funkcji - przede wszystkim mierzy postępy w realizacji strategii, ale właściwie opracowany może pełnić też funkcję informacyjną i komunikacyjną oraz zwiększać transparentność procesu strategicznego. Jego najważniejszą rolą powinno być przekazywanie informacji umożliwiających podejmowanie decyzji o charakterze strategicznym, taktycznym i operacyjnym, czyli przełożenie na proces decyzyjny i zarządczy. Takie podejście wymaga jednak powiązania systemu monitoringu z logika interwencji ${ }^{17}$, czyli doboru wskaźników obrazujących realizację celów strategicznych, operacyjnych i działań. Ich osiagnnięcie powinno oznaczać realizację celów wyższego rzędu zgodnie z logiką przedstawioną na diagramie 2.

$\mathrm{W}$ badanych strategiach dużych miast w Polsce, z wyjątkiem Krakowa, przyjęto pewne założenia dotyczące systemu monitoringu, najczęściej są one jednak bardzo ogólne i zakładają opracowywanie rocznych raportów z monitoringu lub późniejsze opracowanie systemu (tab. 5). Jedynie w trzech miastach (Gdańsk, Katowice, Poznań) przyjęto konkretne wskaźniki kontekstowe powiązane z celami lub wyzwaniami strategicznymi, a w Krakowie sa one prezentowane $\mathrm{w}$ raportach rocznych, nie określono ich jednak na poziomie strategii.

${ }^{17}$ M. Matusiak, Guideline Note, s. 23. 
Tabela 5

Systemy monitoringu strategicznego

\begin{tabular}{|c|c|c|c|c|c|}
\hline Lp. & Miasto & $\begin{array}{c}\text { Założenia } \\
\text { systemu } \\
\text { monitoringu }\end{array}$ & $\begin{array}{c}\text { Wskaźniki } \\
\text { dla celów } \\
\text { strategicznych }\end{array}$ & $\begin{array}{c}\text { Wskaźniki } \\
\text { dla celów } \\
\text { operacyjnych }\end{array}$ & $\begin{array}{c}\text { Wskaźniki } \\
\text { dla działań } \\
\text { strategicznych }\end{array}$ \\
\hline 1. & Gdańsk & $\begin{array}{l}\text { Założenie opra- } \\
\text { cowania systemu } \\
\text { monitoringu }\end{array}$ & $\begin{array}{l}\text { Na poziomie } \\
\text { wyzwań rozwo- } \\
\text { jowych, konteks- } \\
\text { towe }\end{array}$ & Nie przyjęto & Nie przyjęto \\
\hline 2. & Katowice & $\begin{array}{l}\text { Założenie opra- } \\
\text { cowywania ra- } \\
\text { portu z realizacji } \\
\text { strategii rozwoju } \\
\text { miasta }\end{array}$ & Kontekstowe & Nie przyjęto & Nie przyjęto \\
\hline 3. & Kraków & Nie opisano & $\begin{array}{l}\text { Nieprzyjęte na } \\
\text { poziomie strate- } \\
\text { gii, lecz prezen- } \\
\text { towane w rocz- } \\
\text { nych raportach } \\
\text { z realizacji } \\
\text { strategii }\end{array}$ & Nie przyjęto & Nie przyjęto \\
\hline 4. & Łódź & $\begin{array}{l}\text { Założenie mo- } \\
\text { nitorowania } \\
\text { wskaźników na } \\
\text { poziomie progra- } \\
\text { mów i strategii } \\
\text { sektorowych }\end{array}$ & Nie przyjęto & $\begin{array}{l}\text { Wskaźniki pro- } \\
\text { duktu lub rezul- } \\
\text { tatu z wartoś- } \\
\text { ciami bazowymi } \\
\text { i docelowymi dla } \\
\text { niektórych pro- } \\
\text { gramów i strate- } \\
\text { gii sektorowych }\end{array}$ & $\begin{array}{l}\text { Wskaźniki pro- } \\
\text { duktu w ramach } \\
\text { niektórych pro- } \\
\text { gramów i strate- } \\
\text { gii sektorowych }\end{array}$ \\
\hline 5. & Poznań & $\begin{array}{l}\text { Przyjęty system } \\
\text { monitoringu opi- } \\
\text { sany w strategii } \\
\text { i wprowadzony } \\
\text { zarządzeniem } \\
\text { prezydenta. } \\
\text { Coroczny raport } \\
\text { o stanie miasta } \\
\text { oraz raport } \\
\text { z monitoringu } \\
\text { strategii }\end{array}$ & $\begin{array}{l}\text { Kontekstowe dla } \\
\text { celów głównych } \\
\text { strategii i celów } \\
\text { strategicznych } \\
\text { w programach }\end{array}$ & Nie przyjęto & $\begin{array}{l}\text { Wskaźniki pro- } \\
\text { duktu lub rezul- } \\
\text { tatu dla wszyst- } \\
\text { kich działań } \\
\text { strategicznych } \\
\text { z wartościami } \\
\text { bazowymi, po- } \\
\text { średnimi i doce- } \\
\text { lowymi }\end{array}$ \\
\hline 6. & Wrocław & $\begin{array}{l}\text { Ogólne określe- } \\
\text { nie podejścia } \\
\text { do monitoringu } \\
\text { w dokumencie } \\
\text { strategicznym }\end{array}$ & Nie przyjęto & Nie przyjęto & Nie przyjęto \\
\hline 7. & Warszawa & $\begin{array}{l}\text { Przyjęto zało- } \\
\text { żenie publiko- } \\
\text { wania rocznych } \\
\text { raportów z moni- } \\
\text { toringu strategii }\end{array}$ & Nie przyjęto & Nie przyjęto & Nie przyjęto \\
\hline
\end{tabular}

Źródło: opracowanie własne na podstawie dokumentów strategicznych analizowanych miast (zob. tab. 2) oraz ich oficjalnych stron internetowych. 
Warto jednak zwrócić uwagę, że wskaźniki kontekstowe (np. poziom PKB, stopa bezrobocia) obrazuja tylko ogólne trendy rozwoju miast i są najczęściej zależne w większej mierze od czynników zewnętrznych i strukturalnych niż od stopnia realizacji strategii. Ich rola polega na determinowaniu pola interwencji publicznej, jednak sama interwencja powinna być mierzona co najmniej bardziej szczegółowymi wskaźnikami produktu i rezultatu ${ }^{18}$ powiązanymi z celami operacyjnymi i działaniami mierzącymi ich faktyczną realizację. Tego typu wskaźniki przyjęto jedynie w Poznaniu i Łodzi, odpowiednio na poziomie programów strategicznych i programów i strategii sektorowych. W obydwu przypadkach nie rozróżnia się między wskaźnikami produktu i rezultatu, sa one traktowane zamiennie. Poprawność metodologiczna wymaga stosowania wskaźników produktu przede wszystkim na poziomie działań, a rezultatu - na poziomie działań i celów operacyjnych.

Na podstawie przeanalizowanych strategii można stwierdzić, że - z wyjątkiem Poznania i częściowo Łodzi - przyjęte systemy monitoringu mają charakter bardzo ogólny i nie mierzą realnej zmiany strategicznej. Szczególnie niepokojące jest przyjmowanie wskaźników monitoringu dopiero w trakcie realizacji strategii, przy opracowywaniu raportów z jej wdrażania. Takie podejście nie pozwala bowiem na świadome dążenie do osiaggnięcia zmian wskaźników, co zaprzecza zasadom zarządzania strategicznego.

Za najbardziej zaawansowane podejście należy uznać podejście poznańskie, w którym monitorowane są nakłady na realizację strategii, wskaźniki kontekstowe dla celów głównych strategii i celów strategicznych w programach strategicznych, a dodatkowo wskaźniki realizacji działań strategicznych. Zwrócono także uwagę na informacyjną funkcję monitoringu, przedstawiono zmiany wskaźników dla celów głównych strategii w formie pulpitu strategicznego - na bazie logiki świateł drogowych pokazano pozytywne, obojętne lub negatywne zmiany wskaźników strategicznych (diagram 3).

Dla działań strategicznych przyjęto wartości bazowe, pośrednie i docelowe, które prezentowane są w rocznych raportach z monitoringu i dyskutowane na wspólnych posiedzeniach Komitetu Sterującego i Zarządu Miasta. Niezadowalający poziom realizacji wskaźników dla działań strategicznych powinien być podstawą działań naprawczych (zmiany sposobu realizacji działania lub samego działania), docelowo wyniki monitoringu są też podstawą aktualizacji całej strategii. Należy podkreślić, że opracowanie szczegółowego systemu monitoringu strategii wymusiło jej aktualizację, uporządkowania wymagała bowiem logika drzewa celów i precyzja ich sformułowania. Przyjęty system pozwala na pomiar rzeczywistej realizacji strategii i może stanowić podstawę do podejmowania decyzji zarządczych. Kolejnym etapem rozwoju systemu powinno być podjęcie działań ewaluacyjnych badajacych efekty realizacji strategii. Żadne z badanych miast nie prowadziło dotychczas ewaluacji swoich dokumentów strategicznych.

${ }^{18} \mathrm{~W}$ nowych wytycznych dotyczących monitoringu w okresie programowania 2014-2020 Komisja Europejska znacznie ogranicza wykorzystanie wskaźników oddziaływania, zob. Komisja Europejska, op. cit. 


\section{Diagram 3}

System wskaźników kontekstowych dla celów strategicznych w Strategii Rozwoju Poznania

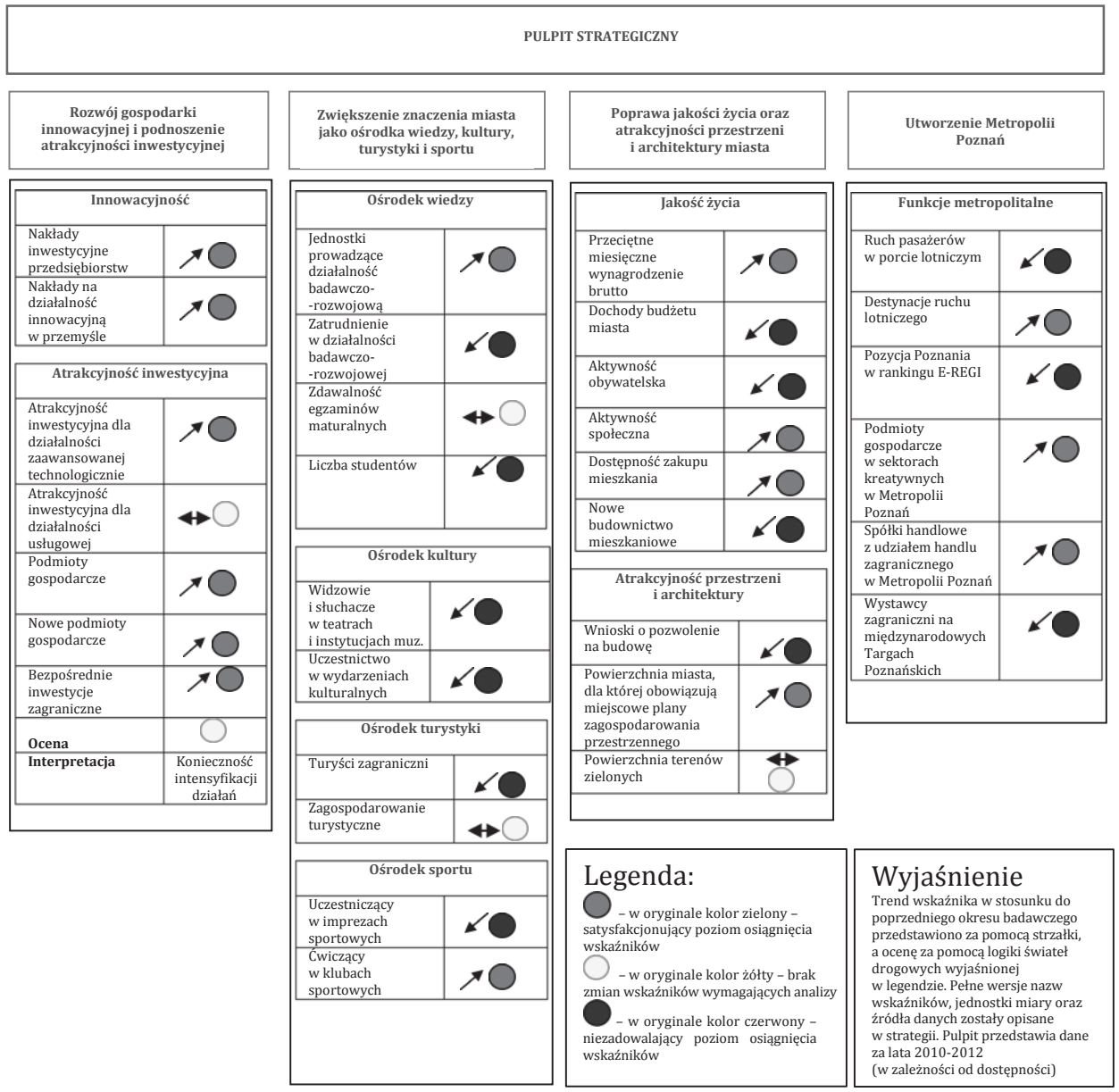

Źródło: Strategia Rozwoju Miasta Poznania do roku 2030, na podstawie koncepcji M. Matusiak, Koncepcja.

Podsumowując analizę systemu monitoringu w badanych miastach, można stwierdzić, że jedynie w przypadku Poznania i częściowo Łodzi można mówić, że istnieje potencjał do wystapienia sprzężenia zwrotnego pomiędzy monitoringiem a zarządzaniem strategicznym w sposób pozwalający na adaptację kierunków działania lub sposobu wdrażania strategii. Wydaje się jednak, że można zidentyfikować pewną ogólną poprawę systemów zarządzania strategicznego, poziom ich zaawansowania jest jednak różny w poszczególnych miastach. 


\section{ZAKOŃCZENIE}

W warunkach szybkich zmian otoczenia i zwiększajacej się globalizacji wymuszającej konkurowanie miast znaczącym wyzwaniem staje się zarządzanie zmianą strategiczna. Zidentyfikowane w artykule problemy wskazują na niewystarczający rozwój systemów zarządzania strategicznego w dużych polskich miastach posiadających znaczące zasoby ludzkie i organizacyjne, co może budzić obawy o zastosowanie zarządzania strategicznego w mniejszych jednostkach. Niewystarczający rozwój systemów monitoringu i brak ich powiązania z systemem zarządzania zmniejsza szanse na wdrożenie zmiany strategicznej w badanych miastach. Najbardziej zaawansowanym podejściem charakteryzuje się Poznań, stosowany system jest jednak dopiero na początkowym etapie rozwoju. Niemniej do znaczących osiagnięć miasta należy zaliczyć system monitoringu odpowiadający logice interwencji, działajacy system wdrażania strategii i jej powiązanie z budżetem zadaniowym. Budowa potencjału w zakresie zarządzania strategicznego miastami wymaga przede wszystkim rozwiązania problemu różnic pomiędzy celami przyjmowanymi w strategiach rozwojowych a świadczonymi usługami publicznymi i kompetencjami samorządów lokalnych. Znacznego rozwoju wymaga także demokratyzacja zarządzania i uspołecznienie procesów wdrażania strategii.

dr Monika Matusiak

Uniwersytet Ekonomiczny w Poznaniu

m.matusiak@ue.poznan.pl

\section{MAKING USE OF THE FEEDBACK MECHANISM IN A STRATEGIC MANAGEMENT OF A CITY}

Summary

Although it is not legally obligatory in Poland to prepare development strategies at local level, most local governments (local authorities) have developed such documents. However, the analysis of the strategic cycle in big Polish cities shows major weaknesses occurring after the planning stage: they can be noted from the design and work of implementation systems to the monitoring and financing of the strategies. Practical usage of the feedback loop in strategic management makes it necessary to join monitoring and management systems. Among seven cities analysed in the research, there is some potential for such a solution only in Poznan and Lodz. Also, none of the cities have used any evaluation tools for their strategies, which makes it difficult to analyse the effects of strategic actions. The growing popularity of urban governance will in the future be a guideline for the development of strategic management systems in Polish cities too. 
